\title{
Challenges Faced by Preschool Teachers in Implementing Physical Activity During Home-Based Teaching and Learning
}

\section{Azizah Zain, Jamilah Mohd Basir, Mohammad Faiz Aiman Mohammad Rafi}

To Link this Article: http://dx.doi.org/10.6007/IJARBSS/v11-i11/11584

DOI:10.6007/IJARBSS/v11-i11/11584

Received: 20 September 2021, Revised: 23 October 2021, Accepted: 05 Novenber 2021

Published Online: 13 November 2021

In-Text Citation: (Zain et al., 2021)

To Cite this Article: Zain, A., Basir, J. M., \& Rafi, M. F. A. M. (2021). Challenges Faced by Preschool Teachers in Implementing Physical Activity During Home-Based Teaching and Learning. International Journal of Academic Research in Business and Social Sciences, 11(11), 910 - 919.

\section{Copyright: (c) 2021 The Author(s)}

Published by Human Resource Management Academic Research Society (www.hrmars.com) This article is published under the Creative Commons Attribution (CC BY 4.0) license. Anyone may reproduce, distribute, translate and create derivative works of this article (for both commercial and non-commercial purposes), subject to full attribution to the original publication and authors. The full terms of this license may be seen at: http://creativecommons.org/licences/by/4.0/legalcode

$$
\text { Vol. 11, No. 11, 2021, Pg. } 910 \text { - } 919
$$

Full Terms \& Conditions of access and use can be found at http://hrmars.com/index.php/pages/detail/publication-ethics 


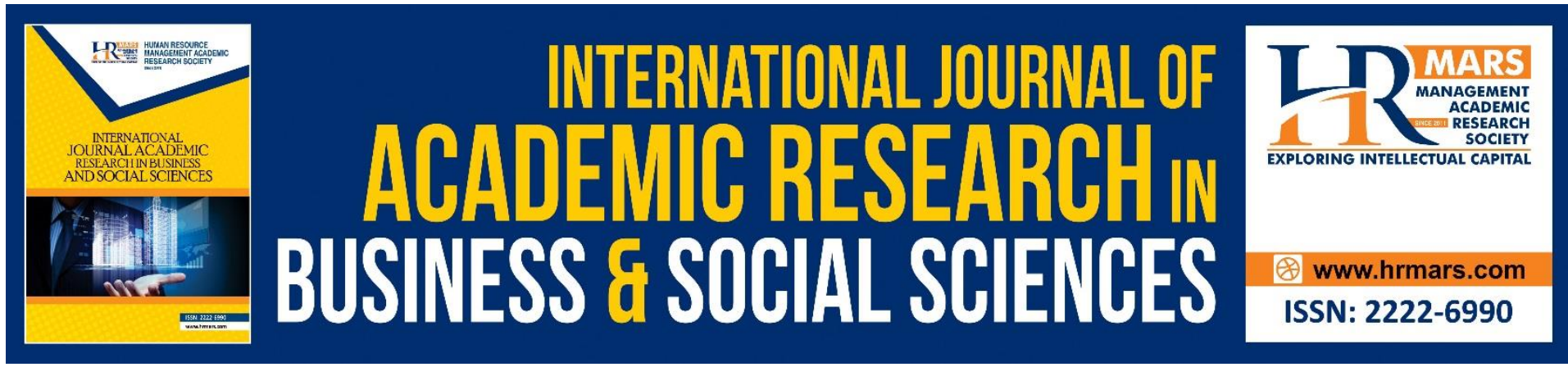

\title{
Challenges Faced by Preschool Teachers in Implementing Physical Activity During Home-Based Teaching and Learning
}

\author{
Azizah Zain ${ }^{1}$, Jamilah Mohd Basir², Mohammad Faiz Aiman \\ Mohammad Rafi ${ }^{3}$ \\ ${ }^{1}$ Fakulti Pembangunan Manusia, Universiti Pendidikan Sultan Idris, Tanjong Malim, Perak, \\ Malaysia, ${ }^{2}$ Fakulti Pembangunan Manusia, Universiti Pendidikan Sultan Idris, Tanjong Malim, \\ Perak, Malaysia, ${ }^{3}$ Fakulti Pembangunan Manusia, Universiti Pendidikan Sultan Idris, Tanjong \\ Malim, Perak, Malaysia \\ Email: azizah.zain@fpm.upsi.edu.my, jamilah.basir@fpm.upsi.edu.my, \\ aiman95rafi@gmail.com
}

\begin{abstract}
Home-based teaching and learning were implemented following the outbreak of COVID-19 in the country as part of an initiative to ensure students are able to learn despite the school closure. Children's physical activity becomes limited when the Movement Control Order was initiated restricts their attendance at school. This study aims to identify the challenges faced by preschool teachers in performing physical activities during home-based teaching and learning. This study uses a quantitative approach with a survey method. A total of 147 preschool teachers from a district in Kedah were randomly selected to answer the questionnaire provided. Data were analyzed descriptively by looking at means and percentages. The findings showed $95 \%$ of teachers stated that they use songs to teach physical activities to children. Barriers and challenges faced by teachers due to children not having good internet access for online learning (54.4\%). Findings for parental support showed they helped children in implementing fine motor and gross motor projects is $81.6 \%$. This study shows that teachers' skills and knowledge in technology are necessary for helping teachers deliver home-based teaching and learning more effectively. Parents also play an important role in ensuring their children to do physical activities at home for their health purpose.
\end{abstract}

Keywords: Challenges, Physical Activity, Home-Based, Teaching and Learning, Preschool Teacher

\section{Introduction}

With the current situation, Malaysia has not been able to address this issue of covid-19 outbreak which has impacted the whole country. Covid-19 transmission resulted many sectors are affected such as the economy, education, and other sectors until Movement Control Order (MCO) was implemented. This measure is aimed at controlling the existing pandemic from spreading further. As a result of this problem, teaching and learning should 
be done online. Online learning has been widely promoted to replace traditional face-to-face learning during the COVID-19 pandemic to maintain young children's learning and playing at home (Dong et al., 2020). Being at home during MCO has hindered the physical activities that children are supposed to do during normal situations.

According to Damanhuri (2016), physical activity can be defined as any limb movement that can increase energy production that involves all body movements such as sitting, getting up, walking, and jumping whether for exercise, recreation, or competition purpose purpose. To improve an individual's health status, a person must be physically active, requiring that individual fitness can be improved overall (US. Department of Health and Human Services, 2004). Physical activity has positive biological and psychological impacts on the brain and cognitive performance, as well as promoting a feeling of well-being (Mandolesi et al., 2018). This does not directly have a beneficial effect on children's academic performance for unrestrained physical activity activities. Children who need this physical activity must not be awkward in a variety of activities throughout the development and growth of the child to any time. Physical activity is fundamental to the early development of every child and affects many aspects of their health. Physical activity also gives benefits to children's health in the short and long term that are important in the physical, emotional, social, and cognitive domains throughout their lifetimes (Zeng et al., 2017)

In the National Preschool Curriculum Standard (NPCS, 2017), physical activities include fine motor development, gross motor skill development, manipulation skills, and rhythmic movement. Indirectly, based on NCPS which has classified certain activities that are appropriate for the age group of children aged four to 6 years. Activities for four-year-old are more focused on activities that are easy to do such as walking, running, climbing, sliding and so on. Meanwhile, there is a slight difference in activities for five-year-old and six-year-old children that children need to play while thinking in doing their physical activity.

The current COVID-19 crisis has obliged most education systems to adopt alternatives for face-to-face teaching and learning. Many education systems resorted to activities online, to allow instruction to continue despite school closures (Organisation for Economic Cooperation and Development, 2020). Following the current situation in Malaysia, the Ministry of Education Malaysia has taken steps to ask all levels of education whether preschool, primary and secondary school to implement teaching and learning at home. Yet there is no denying that there are constraints where not every children have internet facilities and tools. Teachers also face problems in imparting knowledge more effectively through cyberspace. This issue to some extent limits the activities that should be done in helping the child's development in all aspects.

The relatively limited movement of children at home also hinders their physical activity. According to the World Health Organization [WHO], (2011) children and adolescents aged five to 17 years should do physical activity for 60 minutes a day including moderate and high-intensity physical activity. During home based teaching and learning activities for physical activities are quite difficult to carry out. When there is a lack of physical activity outside the classroom or home, children will be less exposed to sunlight. The absorption of vitamin D through sunlight into the child's body will be affected if less exposed (Al-Othman et al., 2012). This lack of vitamin D absorption can endanger children for several types of diseases such as stage 2 diabetes, liver problems, influenza, depression (Rathi \& Sharma, 2017), rickets (Lee et al., 2013), and increased parathyroid levels (Holick et al., 2005). Physical inactivity can lead to increased obesity and decreased cardiorespiratory fitness in children, putting them at 
risk for cardio metabolic disorders and other health issues (Pavlovic et al., 2021). This statement is in line with Dunton et al (2020) that inadequate physical activity and excessive sedentary behavior (SB) in children is a serious problem because children's health behavior patterns tend to persist into adulthood, increasing risk of various serious health conditions (e.g., obesity, type II diabetes, and metabolic syndrome) in childhood and later adulthood.

A study conducted by Hasan et al (2020) showed that physical activity is not given priority in most schools because there is a lack of knowledge about the importance of this activity to students. In fact, some people argue that these activities do not help students' academic achievement. Therefore, this physical education is not given attention by not providing resources and equipment to implement this subject. In addition, parents also do not give support to the school in implementing this activity because they are worried that this activity will cause fatigue and injury to their children. Parents are also concerned that these activities will affect their children's academic achievement. Many parents choose screenbased activities for children that go beyond physical activity. A study by Eyler et al (2021) aimed at exploring parents' perceptions of changes in children's physical activity during home stay order COVID-19 showed data from 245 (63.7\%) parents reported decreased children's physical activity during stay-at-home orders

The implementation of physical activities requires space so that movement can be done effectively. In addition, the use of teaching aids can also help in teaching and learning in physical activities. However, when the Covid 19 pandemic hit the country, all these activities were somewhat stalled because schools were closed and children did not have the opportunity to go to school during movement control. Therefore, this study was conducted to answer the following research questions through an online survey:

1. Do teachers perform physical activity during the Covid-19 pandemic?

2. What are the challenges faced by preschool teachers in performing physical activities during the Covid-19 pandemic?

3. What do parents do in helping preschool teachers process physical activity during the Covid -19 pandemic?

\section{Method}

\section{Study Design}

The design of this study uses a qualitative approach with survey method. Data is collected online using Google Forms. This study was conducted on 147 preschool teachers in a district in the state of Kedah. To obtain feedback from preschool teachers on the challenges faced by preschool teachers in implementing physical activities in preschools, several procedures were passed. Questionnaires were evaluated and validated by content experts and language experts. After obtaining confirmation from the experts, the researchers modified the revised questionnaire based on the expert's views. Pilot studies are conducted because pilot studies can overcome negative risks, questionnaire structure and also grammatical usage errors can be reduced and researchers can gain meaningful experience (Fraenkel \& Wallen, 2006; Leedy \& Ormrod, 2001; Gay \& Airasian, 2000).

\section{Questionnaire}

The questionnaire consists of three parts and includes 31 closed questions. The closed questions and rating scales generate an overview challenges faced by preschool teachers in implementing physical activity during home-based teaching and learning 
Part I: Demographic information. This part has four questions and collects the demographic information of the participants. The questions include the participants' age, qualifications and their nation.

Part II: Identify the implementation of physical activity to preschool children during covid19 by preschool teachers. This section aims to find out how teachers perform physical activities during teaching and learning at home with 8 questions. All of these questions were used to investigate the mode of implementation and the medium used to deliver teaching and learning.

Part III: Identify the challenges of preschool teachers in implementing physical activities during covid 19 This section adopted a five-point Likert scale (ranging from "strongly disagree" to "strongly agree") to ask for teacher's challenges in implementing physical activities during covid 19 with 13 questions

Part IV: Identify parental support in assisting teachers perform Covid-19 physical activity 19. This section aims to identify the support provided by parents to teachers as they implement online teaching and learning. The questions of this section contain 10 questions that must be answered "Yes" or "No" by the teacher.

\section{Procedure}

The survey was conducted in mid -June 2021 after the school's preschools were closed and control orders were implemented. All teachers and children have gained a lot of experience with online learning. Teachers are given a google form link to answer this questionnaire. Participants were clearly informed throughout the study that participation in the research was entirely voluntary, and they were able to withdraw their participation at any time for no reason.

\section{Results}

Implementation of Physical Activity to Preschool Children During Covid-19 by Preschool Teachers

There were 8 questions in the first research question that had to be answered by preschool teachers related to the implementation of physical activity to preschool children during covid19. They only need to answer "Yes" or "No" in this section.

Findings showed the highest percentage (95\%) of teachers stated 'yes', they use songs that have movement to teach physical activity. The findings of the study also showed that most teachers use WhatsApp application (74.8\%) in teaching and learning physical activities with children compared to other applications such as Google Meet (6.8\%) and Zoom (4.1\%). Only 75 teachers implemented the teaching and learning of physical activities online. 
Table 1: Implementation of Physical Activity to Preschool Children During Covid-19

\begin{tabular}{|c|c|c|c|c|c|}
\hline \multirow[t]{2}{*}{ No. } & \multirow[t]{2}{*}{ Question } & \multicolumn{2}{|c|}{ Yes } & \multicolumn{2}{|c|}{ No } \\
\hline & & $\%$ & $\mathbf{N}$ & $\%$ & $\mathbf{N}$ \\
\hline 1 & I teach physical activity online during covid-19 & 51 & 75 & 49 & 72 \\
\hline 2 & $\begin{array}{l}\text { I use the Google Meet app to teach physical } \\
\text { activity }\end{array}$ & 7 & 10 & 93 & 137 \\
\hline 3 & I use the Zoom app to teach physical activity. & 4 & 6 & 96 & 141 \\
\hline 4 & $\begin{array}{l}\text { I use the WhatsApp app to teach physical } \\
\text { activity }\end{array}$ & 75 & 110 & 25 & 37 \\
\hline 5 & $\begin{array}{l}\text { I use workbooks given to parents to teach } \\
\text { physical activity }\end{array}$ & 53 & 7 & 47 & 69 \\
\hline 6 & $\begin{array}{l}\text { I asked the children to do a fine/rough motor } \\
\text { project }\end{array}$ & 88. & 129 & 12 & 18 \\
\hline 7 & I use songs that have movement to teach & 95 & 140 & 5 & 7 \\
\hline 8 & I teach according to the timetable & 86 & 126 & 14 & 21 \\
\hline
\end{tabular}

\section{Challenges Faced by Preschool Teachers In Implementing Physical Activity}

The findings of this section aim to identify the challenges faced by teachers related to the implementation of physical activities in teaching and learning at home. Table 2.0 shows the research findings for this research question. The results showed that the main challenge faced by preschool teachers is the problem of internet access faced by preschool children to follow the teaching and learning at home. The results showed that $54.4 \%$ of teachers (agree and strongly agree) stated that children have problems accessing the internet.

Home based teaching and learning that is implemented online is actually less suitable to be implemented with children. Findings showed that $45.6 \%$ of teachers (agree and strongly agree) stated that children are passive and pay less attention during home based teaching and learning implementation.

The findings also showed that children are easily bored when online teaching and learning is implemented with $42 \%$ of teachers (agreeing and strongly agreeing) on this. However, almost $68.7 \%$ of these teachers do not agree with the statement that they do not have the skills and knowledge in ICT skills.

The findings also showed that teachers have skills and knowledge in ICT. The percentage of teachers who disagreed with their statement of lack of skills and knowledge in ICT was $68.7 \%$. These findings indicate that most teachers have skills in the use of ICT skills. Teachers also do not agree with the statement that they do not know how to use applications in online learning with a percentage 
Table 2: Identify the challenges of preschool teachers in performing preschool physical activities during covid 19

\begin{tabular}{|c|c|c|c|c|c|c|}
\hline \multirow[t]{2}{*}{ Item } & \multirow[t]{2}{*}{ Statement } & \multicolumn{5}{|c|}{ Percentage (\%) } \\
\hline & & SD & D & $\mathbf{N}$ & A & SA \\
\hline 1 & I don't have good internet access & 17.0 & 39.5 & 7.5 & 28.6 & 7.5 \\
\hline 2 & $\begin{array}{l}\text { I have no skills and knowledge in ICT } \\
\text { skills }\end{array}$ & 17.7 & 51.0 & 15.0 & 15.6 & 0.7 \\
\hline 3 & $\begin{array}{l}\text { I do not know how to use applications in } \\
\text { online learning }\end{array}$ & 17.0 & 51.0 & 17.0 & 15.0 & 5.0 \\
\hline 4 & $\begin{array}{l}\text { I don't have the right gadget facility for } \\
\text { online learning }\end{array}$ & 23.1 & 43.5 & 11.6 & 20.4 & 1.4 \\
\hline 5 & $\begin{array}{l}\text { I use the equipment with other family } \\
\text { members }\end{array}$ & 32.7 & 30.6 & 10.2 & 23.1 & 3.4 \\
\hline 6 & $\begin{array}{l}\text { Parents ignore the instructions given by } \\
\text { the teacher }\end{array}$ & 10.2 & 42.2 & 26.5 & 17.0 & 4.1 \\
\hline 7 & $\begin{array}{l}\text { Parents are not committed to their } \\
\text { children in online learning }\end{array}$ & 8.2 & 41.5 & 24.5 & 21.1 & 4.8 \\
\hline 8 & $\begin{array}{l}\text { Parents are more focused on their } \\
\text { children's academic education than } \\
\text { physical activity }\end{array}$ & 2.7 & 21.1 & 32.0 & 37.4 & 6.8 \\
\hline 9 & $\begin{array}{l}\text { Children do not have good internet } \\
\text { access for online learning }\end{array}$ & 3.4 & 15.6 & 26.5 & 37.4 & 17.0 \\
\hline 10 & $\begin{array}{l}\text { Children are more interested in reading } \\
\text { activities }\end{array}$ & 4.8 & 42.2 & 25.9 & 22.4 & 4.8 \\
\hline 11 & $\begin{array}{l}\text { Children are less interested in online } \\
\text { classes }\end{array}$ & 6.1 & 19.0 & 36.7 & 32.7 & 5.4 \\
\hline 12 & $\begin{array}{l}\text { Children are easily bored with the class } \\
\text { online. }\end{array}$ & 4.1 & 21.8 & 32.0 & 36.7 & 5.4 \\
\hline 13 & $\begin{array}{l}\text { Children are more passive when } \\
\text { learning online }\end{array}$ & 3.4 & 19.7 & 31.3 & 37.4 & 8.2 \\
\hline
\end{tabular}

\section{Parental Support in Helping Teachers Perform Covid-19 Physical Activities}

In this third research question, researchers want to obtain information related to parental support in helping teachers perform physical activities through teaching and learning at home.

Findings showed that $81.6 \%$ of teachers stated that parents also help their children in activities that involve fine motor and gross motor. This shows that parents give cooperation and support to teachers in helping their children's education at home

Findings for this research question also found that a moderate percentage (69.4\%) is for the 6th item that is parents are always in touch with teachers to find out the level of development of children. The findings also found that $70 \%$ of teachers stated that parents do not provide support in recording activities performed by children during teaching and learning at home. 
Figure 3: Parent support in helping teachers perform the physical activity of Covid 19

\begin{tabular}{|c|c|c|c|}
\hline No. & Item & Yes & No \\
\hline 1 & Parents provide gadgets for online learning & $46.3 \%$ & $53.7 \%$ \\
\hline 2 & Parents are involved during physical activity & $52.4 \%$ & $47.6 \%$ \\
\hline 3 & Parents provide good internet access & $44.9 \%$ & $55.1 \%$ \\
\hline 4 & $\begin{array}{l}\text { Parents are always in touch with teachers to find out the level } \\
\text { of development of children }\end{array}$ & $69.4 \%$ & $30.6 \%$ \\
\hline 5 & $\begin{array}{l}\text { Parents provide a space for physical activities to be conducted } \\
\text { during online learning }\end{array}$ & $49.7 \%$ & $50.3 \%$ \\
\hline 6 & Parents provide materials for children's physical activities & $59.2 \%$ & $40.8 \%$ \\
\hline 7 & $\begin{array}{l}\text { Parents recorded activities and shared videos of children doing } \\
\text { physical activities at home }\end{array}$ & $63.3 \%$ & $36.7 \%$ \\
\hline 8 & Parents provide physical activity learning materials & $55.1 \%$ & $44.9 \%$ \\
\hline 9 & Parents record the physical development of children & $29.9 \%$ & $70.1 \%$ \\
\hline 10 & Parents help in a fine motor project and rough motor & $81.6 \%$ & $18.4 \%$ \\
\hline
\end{tabular}

\section{Discussion}

The COVID-19 pandemic has an impact on children's lives. The lives of those who were previously free to do any play activities were quite limited by the presence of movement control order and school closures. This condition to some extent has affected their development and also disrupted their daily activities that were supposed to take place. This pandemic resulted in increased of obesity, pain, depression, anxiety, feelings of loneliness, and sleep disturbances which linked to the declining levels of physical activity.

In this study, the results show that physical activity can still be performed through teaching and learning at home despite some obstacles in its implementation. Results show that teachers have skills in the use of apps that help them to do physical activities with children. The problem of internet access by children can be solved by providing materials offline or giving tasks that can be done by children with the help of parents. In addition, the role of parents is very important in helping their children to do physical activities at home. Parental involvement can help physical development well during this pandemic season. Teachers need to be more creative in their lesson delivery which requires children to be able to perform physical activities in this pandemic situation.

Physical activities can be varied to spike the interest of children so that they do not feel bored. Teachers can involve parents or other siblings in physical activities so that children feel fun throughout the process. The involvement of family members can help children emotionally and socially while at home. Children's interest in physical activity can be done by using interesting songs and videos. The use of songs and videos can reduce their boredom and make teaching and learning at home more meaningful and exciting. 


\section{Conclusion}

Physical activity is one of the crucial activities in helping the physical development of children and these skills are contained in the national standard preschool curriculum. However, due to the Movement Control Order (MCO), online teaching and learning implementation resulted these activities are not performed in the exact amount of time. More focus is given to children's mastery in academics such as mastery in 3M. Home teaching and learning should be planned by taking physical activities into consideration so that the children can proactively move and promote their physical development. Apart from teachers, parents also need to do physical activities with their children at home. Various movements can be done despite the relatively limited space conditions to ensure the child's health is guaranteed.

\section{References}

Al-Othman, A., Al-Musharaf, S., Al-Daghri, N. M., Krishnaswamy, S., Yusuf, D. S., Alkharfy, K. M., ... \& Chrousos, G. P. (2012). Effect of physical activity and sun exposure on vitamin D status of Saudi children and adolescents. BMC pediatrics, 12(1), 1-6. https://doi.org/10.1186/1471-2431-12-92

Eyler, A. A., Schmidt, L., Kepper, M., Mazzucca, S., Gilbert, A., \& Beck, A. (2021). Parent perceptions of changes in child physical activity during COVID-19 stay-at-home orders. Frontiers in Public Health, 9, 1-8. https://doi.org/10.3389/fpubh.2021.637151

Damanhuri, Z. (2016). Perbezaan Aspek Perkembangan Fizikal Dalam Kalangan Kanak-Kanak Lelaki Dan Perempuan Menurut Perspektif Barat. Jurnal Sains Sosial: Malaysian Journal of Social Sciences, 1(1), 137-148. Retrived from https://journal.kuim.edu.my/index.php/JSS/article/download/56/

Dong, C., Cao, S., \& Li, H. (2020). Young children's online learning during COVID-19 pandemic: Chinese parents' beliefs and attitudes. Children and youth services review, 118, 105440. https://doi.org/10.1016/j.childyouth.2020.105440

Dunton, G. F., Do, B., \& Wang, S. D. (2020). Early effects of the COVID-19 pandemic on physical activity and sedentary behavior in children living in the US. BMC Public Health, 20(1), 1-13. https://doi.org/10.1186/s12889-020-09429-3

Fraenkel, J. R., \& Wallen, N. E. (2006). How to design and evaluate research in education (6th ed.). New York, NY: McGraw-Hill.

Gay, L. R., \& Airasian, P. W. (2000). Student guide to accompany educational research: Competencies for analysis and application. Merill.

Hasan, A. R., Rashid, M. H., Smith, G., Selim, M. A., \& Rasheed, S. (2020). Challenges of promoting physical activity among school children in urban Bangladesh: a qualitative inquiry. PloS one, 15(3), e0230321. https://doi.org/10.1371/journal.pone.0230321

Holick, M. F., Siris, E. S., Binkley, N., Beard, M. K., Khan, A., Katzer, J. T., ... \& de Papp, A. E. (2005). Prevalence of vitamin D inadequacy among postmenopausal North American women receiving osteoporosis therapy. The Journal of Clinical Endocrinology \& Metabolism, 90(6), 3215-3224. https://doi.org/10.1210/jc.2004-2364

Lee, J. Y., So, T. Y., \& Thackray, J. (2013). A review on vitamin d deficiency treatment in pediatric patients. The Journal of Pediatric Pharmacology and Therapeutics, 18(4), 277-291. https://doi.org/10.5863/1551-6776-18.4.277

Leedy, P., \& Ormrod, J. (2001). Practical Research: Planning and Design (7th ed.). Merrill Prentice Hall and SAGE Publications, Upper Saddle River, NJ and Thousand Oaks, CA. 
Mandolesi, L., Polverino, A., Montuori, S., Foti, F., Ferraioli, G., Sorrentino, P., \& Sorrentino, G. (2018). Effects of physical exercise on cognitive functioning and wellbeing: biological and psychological benefits. Frontiers in psychology, 9, 509. https://doi.org/10.3389/fpsyg.2018.00509

Ministry of Education Malaysia [MOE]. (2017). National Preschool Standard Curriculum. Putrajaya: Curriculum Development Division.

Organisation for Economic Co-operation and Development [OECD]. (2020). Learning remotely when schools close: How well are students and schools prepared? Insights from PISA. Paris: OECD Publishing.

Pavlovic, A., DeFina, L. F., Natale, B. L., Thiele, S. E., Walker, T. J., Craig, D. W., ... \& Kohl, H. W. (2021). Keeping children healthy during and after COVID-19 pandemic: meeting youth physical activity needs. BMC public health, 21(1), 1-8. https://doi.org/10.1186/s12889-021-10545-x

Rathi, A., \& Sharma, P. (2017). Vitamin D Deficiency and Its Related Health Effects: An Indian Perspective. International Journal of Innovative Research and Advanced Studies (IJIRAS), 4(3), 178-181. Retrived from https://www.ijiras.com/2017/Vol_4Issue_3/paper_37.pdf

Zeng, N., Ayyub, M., Sun, H., Wen, X., Xiang, P., \& Gao, Z. (2017). Effects of physical activity on motor skills and cognitive development in early childhood: a systematic review. BioMed research international, 1-13. https://doi.org/10.1155/2017/2760716 